\title{
The Role of Organizational Values in Commitment of Employees
}

\author{
Mustafa AbdulAbaass $^{1}$, Nisreen Jasim Mohammed $^{2}$ \\ ${ }^{1}$ Department of Public Administration. College of Administration and Economics. University of Baghdad, Al Wazeria. Baghdad. Iraq \\ ${ }^{2}$ Department of Business Administration. College of Administration and Economics. Baghdad University, Al Wazeria. Baghdad. Iraq
}

\begin{abstract}
The current research aims to diagnose the correlation \& effect relationship between the organizational values including ( Reward values, Justice values, and value of teamwork) as dependent variable and employees commitment including (Emotional commitment, Normative commitment, and Ongoing commitment) as an independent variable. The study was conducted on a random sample consisting of (50) employees from different departments at the General company for electric and electronic industries - Iraq. We use questionnaire as tool for collecting information, then we analyzed these information by using (spss) program. Our findings suggested that there is a correlation and effect relationship between organizational values and commitment of employees. Organizational values plan crucial role in making employees more committed and in deepening the spirit of belonging and organizational loyalty. Value of justice and the value of teamwork have on effect on deepening the ongoing commitment with the organization. The most important recommendation is to increase the investment of organizations in both concepts Organizational value and organizational commitment and give them more attention priority because of their positive effect on the strategic performance of organization achieving the goals.
\end{abstract}

Keywords: organizational values, organizational commitment.

\section{Introduction}

Traditionally, organizations operate under system and regulation of a vary central nature without giving least attention to human element, where human was treated as a machine created in order to do work only. This situation continued until the emergence of the theory of human relation from (Elton May and his colleagues) and it was found in Hawthorne's experiments organization that there is organization imposed by the relationship between employees on the way of doing work within organization. Developments in the twenty -first century have increased the role of organizations and the challenges they face, this has made organizations more focused on the behavioral aspects of employees as a key factor for success. Organization in any society are reflection of the reality of that society and its customer, traditions, beliefs, and values. The way the organization performs its work is consistent with what the community believes, and every organization has a set of values - whether realized or not - which is the most important factor that distinguish the organization from the other organizations. The organizational values are fundamental factor that requires adequate attention from organizations, because values are the main driver of the behavior of employees in the way of doing work and determining what is good and bad within organization. Individual's beliefs in the values adopted by the organization and their compatibility with their goals and personal values generate the commitment and job satisfaction towards organization and the nature of works they perform. Successful organizations are looking at organizational values as a long-term investment that works to achieve strategic success. The literature recall that the ways in which organizations are managed have changed at the turn of the twentieth century from (management guidance) to (management by objective) and then to (management by values). Peters \& Waterman (1982) are the first who realized the importance of values for the organization under (Makinsey 7S) model and the central role that played as a common denominator in all functions and works of the organization, making the organization capable of success.

\section{Review of References}

2.1 The historical evolution of organizational values in administrative thought

Stage 1 / Focus on rationality: The values prevailed in administrative thought during this period were that man should be treated on the basis that he is similar to machine and can be motivated by material gains. The pioneers of this stage are (Frederick Taylor and Max Weber). This view had to be changed due to the lack of consideration of the employees feelings and the nature of the human relations prevailing in the work, and the fact that the workers as machines can be stimulated by money only.

Stage 2 / Focusing on emotions : This stage began with the movement of Human Relations management, the results of Hawthorne study had a significant impact on the emergence of values related to professional relations and morale of employees in the workplace, as well as the values of training, positive attitudes toward work and methods of motivating employees [1].

Stage 3 / Focus on confrontation: This stage was reflected in the evolution of organizational values in response to the emergence of labor unions. These unions have considerable strength due to large losses in organizations resulting from chaos and disruption. Therefore, the management adopted new approaches for work other than fighting to solve

Volume 6 Issue 12, December 2017 


\section{International Journal of Science and Research (IJSR) \\ ISSN (Online): 2319-7064}

Index Copernicus Value (2015): 78.96 | Impact Factor (2015): 6.391

problems, which led to the emergence of the values of freedom in the work environment [2].

Stage 4 / Focus on consensus in opinion: This stage is based on freedom at workplace. In the year ( 1960), (Douglas Mc Gregor) explained the importance of administrative value systems by dividing the person into two opposing groups: person (X) who classified as a lazy, unreliable, and dislike work, while person is a positive, selfmotivated and has a desire to work.

Stage 5/ Focus on individual organization and individual balance: It is also called the phase of management by objectives. According to this theory, each person should have a comprehensive and agreed productivity goals, but allows to individuals to choose the means of achieving these goal. The aim of this theory is to align the needs of the individual with the organizational management by goals is more suitable in relatively of bureaucracy in its bad sense of long processes [3].

Stage 6 / Focus on capabilities: It is also called the stage of (organizational development). its refers to the planned and elaborated effort supported by top management in order to increase the efficiency and effectiveness of administrative organization. During this stage, there are new values represented by the analysis of ideas and management information and the use of scientific research methodology.

Stage 7: Focus on the Realism: During this stage, the evolution of organizational values are achieved by integrating the previous evolution's stage of the value. After decades of rushing and working without a specific goal, the managers realized that they were dealing with a difficult task in terms of leadership and discipline, dealing with environmental threats and global competition. therefore the most efficient organization will survive. this stage emerge during 1970 s as a reaction to the previous stages that considered as introductory stage. This phase witnessed the spread of certain values such as (self- responsibility) (Nothing is free), and ( hard work leads to success ) [4].

\subsection{The concept of organizational values}

Organizational values are core of all managerial practices, but organization do not recognize this and do not give it enough attention [5].Values underpin the methods of work and the design of organization, the direction of structure and systems, and the identification of job within the organization, and any change in the structure of the value should be accompanied by a change in the structure of the organization [6]. Values play an important role in defining the vision and mission of organization, as values are considered a part of a basic ideology directed to the vision and mission of the Organization [7].The researchers have addressed the concept of organizational values from different aspects ,the organizational values defined as asset of beliefs about what is appropriate and in appropriate organizational behavior [8]. And defined the organizational values that shared by all or most members of the organization, and as an indicator of organizational practices [9]. Indicate organizational values that the basic principles of organization that help guide the correct actions of the organization [10]. while defined the organizational values as collective beliefs, assumptions and fillings about, natural, rational, and high value things [11]. And defined organizational values that the commonalities among individuals within an organization that give the ability to distinguish between good and evil , and whit is acceptable and rejected [12].

\subsection{The congruence between individual values and organization values}

In recent years was an increased interest in the search for the effect of the relationship between individual values and organization values. There is need to achieve a match between the individual values and organizational value, as a result of changes in environment and to make employees more connected with the organization. In order to understand the congruence between them, there are three important approaches that organizations need to consider [13].

- Congruence between the values of top managers and subordinates.

- Congruence between values colleagues.

- Congruence between values of individual and organization, and the third approach as the most relearnt for understanding this relationship that is known as congruence model.

The concept of congruence refers to the degree to which the needs, objectives or structures of a given entity are consistent with the needs objectives and structures of another entity. To ensure the organizational success, the values of organization should be consistent with values of employees [14]. The behavior of citizenship and organizational identity in administrative science aims to motivate individuals and provide a positive organizational climate and seek ways to reduce the pressures of work in order to attract new human resources while the current ours, and the congruence between organizational and individual is one important ways to achieve this. If there is incongruity between organizational and individual values, this will leads to gaps and inconsistences in values, increase conflict and tension, and increasing the complexity of managerial work [15]. While the congruence between these values leads to increase the loyalty of individual working in organization [16].As well as, there is a correlation between organizational and individual values and commitment of employees. Individuals whose organizational and individual values are more congruent are more committed to wards their organization. Individuals whose organizational and individual values are less clear are less positive and less interested to work of their organizations [17]. Figure (1) illustrates the importance of congruence between organizational and individual values, leading to ethical behavior and organizational commitment by members of organization. 


\section{International Journal of Science and Research (IJSR)}

ISSN (Online): 2319-7064

Index Copernicus Value (2015): 78.96 | Impact Factor (2015): 6.391

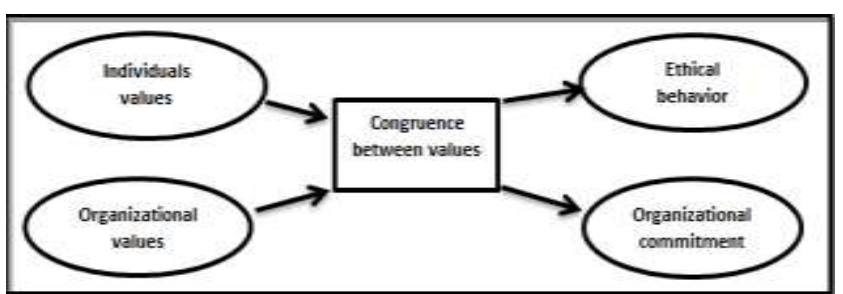

Figure 1: The congruence between individual values and organizational values

Based on the above, organizations should now study and understand the personal values of individuals, understanding their goals and needs, and work to achieve them in a manner consistent with the core values of the organization, because the lack of awareness of this fundamental point leads to conflict between the individual and the organization, as each of them will pursue its interests at the expense of the other, this will course adverse consequences on the performance of the Organization as shown in the following figure:

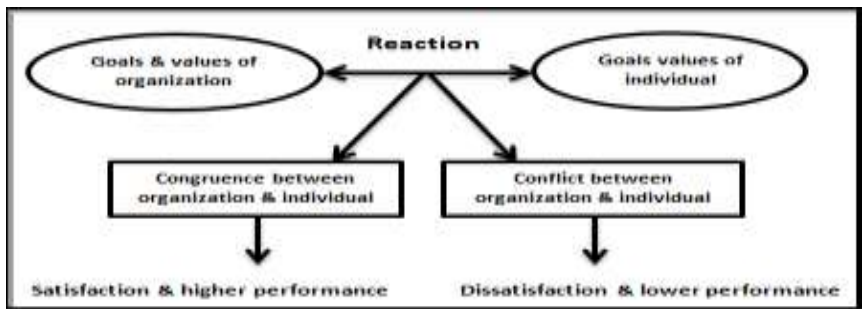

Figure 2: The congruence between individual values and organizational values

\subsection{Dimension of organizational values}

- Reward: Reward are a form of incentive that drives individual to work, as anticipating incentives is a powerful factor in driving people's behavior and raising performance. They define incentives as "a set of influences that are used to influence the behavior of an individual and to determine the shape of his behavior and satisfy his motivational needs" [18]. The importance of incentives system lies in creating motivation among employees by linking their personal objectives with the overall goals of organization[19]. Rewards serves as a tool for raising morale and increasing loyalty and belonging to the organization. Good performance of managers is vital to achieve the goals of the organization. Since the good performance of manager is an essential for achieving the organization goals, Successful organizations are the once which are able to recognize the success and reward it. This Organization adopts the value of " performance - king" [3].

- Justice: Justice refers to fairness and equality of organizations towards employees [20]. This value is a prerequisite for achieving the objectives of the organization. Where positive feeling of employees about justice within the organization generates satisfaction increases loyalty, increases confidence of subordinates with their top management, and reduces the pressures of work. Justice can be views as equity of wages, bonus, and rewards as well as equity in distribution of workloads [21]. Actually, organization's justice will lead to higher level of loyalty and commitment towards organization, if employees felt that they were being treated unfair and ignored, the levels of loyalty and commitment will be low [22]. Therefore, organization most understand the view of the employees and take them into consideration, those organization adopts the value of " who care will gain " [23].

- Teamwork : They are a small group of individuals whose combined individual efforts result in greater performance than the sum of all individual inputs (Robbins \& Judge, 2007: 339) [24]. Organizations are now focusing on teamwork to do business in order to achieve the objective of organization efficiently and effectively [25]. The more organized and selfcontained groups, the higher levels performance [26]. Therefore, organization adopt the value "working together harmoniously " [3].

\section{The Concept of Organizational Commitment}

Organization commitment is one of the subjects that has attracted the attention of researchers for a long time. Becker study in 1960 in the United States of America is the first studies on this concept and become the basis for all current research. Becker argue that the commitment a psychological phenomenon because individual stays at the organization as long as the input are increasing. This study is the basis for all research on the subject of organizational commitment [27]. Defined the commitment as the process of faith in the organization's goals and values, and exerting maximum effort in order to achieve these goals and embodiment of these values [28]. And defined the organizational commitment is the strength of the individual's conformity with his organization and the extent of his association with the organization [29]. While defined commitment as an emotional orientation towards the organization, realizing the costs associated with leaving the Organization and a normative commitment to stay with the organization [30]. In the same vein defined, commitment as a set of internal standards that lead to behavior in a manner that is consistent with the objective and interests of the organization [31]. And another one defined it is a state of loyalty and an inner sense of the individual making a high-level effort in which he hopes to increase the effectiveness of the organization [32]. while affined the organizational commitment as a sense of individual belonging and organizational identification when engaging in a particular organization [33]. Another researchers indicated that it combines internal normative requirements to unite in a particular pattern that meets the interests, objectives and values of the [34].

\subsection{The importance of_organizational commitment}

The organizational commitment leads to several types of behavioral output that are important for all organizations and that lead to positive results for survive and success the organization, such as high and low turnover and high performance in addition to the high moral among employees as well as decreasing the problems of work between employees and management [35]. Individuals who have high levels of organizational commitment are characterized by outstanding job performance that leads to increased productivity and loyalty for a long time and feel that they

\section{Volume 6 Issue 12, December 2017}




\section{International Journal of Science and Research (IJSR) \\ ISSN (Online): 2319-7064}

Index Copernicus Value (2015): 78.96 | Impact Factor (2015): 6.391

satisfy their needs are met and more likely to have strong cohesion with their organization ,thus, increasing their commitment towards the organization and decreasing the turnover and absence [36]. That the studies have shown the high level of organizational commitment in work environment leads to decrease in the level of negative consequence, especially the phenomenon of absence and evasion of work [37]. The organizational commitment is important and has impact on the individual and the organization, as it is an indicator of predicting the outputs of the organization such as performance, job evasion and the absence of workers [38]. The organizational commitment is important to achieve and maintaining customer satisfaction, because employees who stay longer in the organization have better knowledge about the desired business practices, and customers want to deal with employees themselves. Therefor managers always need to create loyalty among employees in favor of the organization, and offer support for them, which reduce the organizational conflict within the organization [39].

\subsection{The approaches of organizational values}

1-Attitudinal approach: This approach defines commitment as employee attitudes or a set of behavioral, commitment is the relative strength of individual's identification and the extent of their involvement in the organization. Based on this approach, the factors associated with the commitment are: as positive work experiences, personal characteristics, and functional characteristics. Outputs include performance, reduced the absences, and turnover.

2- Behavioral approach: This approach defines commitment as the behavior of employee within an organization views that employee's continuation with organization is depend on arrange of investments (such as time spent in the organization, friendships formed within the organization, and the pension). According the to this approach, the commitment is determined by the benefits associated with the continuation of work in the organization versus the cost associated with leaving. This approach refers to investments as the strength that binds individual to organization. [40].

3- Psychological approach: This approach defined the organizational commitment through three: (the desire to exert a great effort for organization, the need of employee to remain a member of the organization, and the acceptance and belief in the goals of the Organization) [41]. And defined it's the commitment is driven by a set of emotional like as well as social [42].

4- Reciprocal approach: This approach is consistent with the theory of organizational balance of Herbert Simon, which is based on the assumption that the individual's contribution as much as his expectations of benefits [43].

5- Multidimensional approach: This approach defines the commitment as a combination emotional connection, perceived cost, and moral commitment. The organizational commitment result from interaction of these three components, and the organizational commitment consists of three dimensions (ethical participation is a positive orientation that depends on congruence with the organization goals). (The perceived participation which is either in positive direction or negative, depending on the benefits that the individual receive versus his or her effort. (Transitional participation which is a negative orientation, where people continue to work with organization because they are unable to change their environment and have no other option [40].

\subsection{Dimensions of Organizational Commitment}

- Emotional commitment: It refers to the commitment based on the emotional ties developed by the individual with the organization as a result of positive experiences (Sulu, et.al, 2010: 29) [48]. While defined the emotional commitment as the employee's relation and with its goals, and the employee's desire to keep working with his or her organization [44]. Another one defined the emotional commitment as the extent to which employees feel committed towards their organization by virtue of balancing the costs associated with leaving the job, emotional commitment is emotional bond with organization and employee's belief in the values of organization [45].

- Normative commitment: The normative obligation is defined as the commit employee, and his other to stay in the organization [46]. While another researchers defined normative commitment as responsibility employee towards his that is characteristics by believing that loyalty is a normal case absorbing the fact that he must stay in organization until retired, and the believing that he must sacrificed for the organization [47]. And While defined the normative commitment as keeping work with organization due to social responsibility from long-term social effects [27]. As will defined it's the commitment to keep working with organization due to feeling that continuing to work in organizational is moral duty [48].

- Ongoing commitment: The ongoing commitment is based on realizing the necessity of staying in the organization, they pointed out that the continuous commitment consists of two separate components (perceived sacrifice associated with leaving work and lack of job options) [49]. The ongoing commitment is a commitment based on the expected costs of leaving the organization, both economically and socially [44].

\section{Research Methodology}

\subsection{Research problem}

Organization are experiencing various developments including improved means of delivery of services in all areas. Organization has a unique features, such as values, orientations, and standards that distinguish the organization from other organizational. Values constitute behaviors and effect on activities performed by the organization. The human resources are crucial to achieve the organizational goals. Undoubtedly, the greater the commitment and loyalty towards organization, the more effectiveness of organization. At the field level it became clear through the field visits that

\section{Volume 6 Issue 12, December 2017}




\section{International Journal of Science and Research (IJSR) \\ ISSN (Online): 2319-7064}

Index Copernicus Value (2015): 78.96 | Impact Factor (2015): 6.391

the General Company for Electrical and Electronic in Iraq which represent the simple in question- suffer from ambiguity of organizational values that the employees experienced, and there are absence of regulations that determine what values should be complied with when doing business. In light of above, the problem of the research is determined by the relationship between organizational values the commitment of employees. In other words, the problem of research is determined by answering the following question: (Do organizational values effect on employee commitment?).

\subsection{The sample}

The sample consists of (50) employees was selected randomly working in the various division of the General company for electrical and electronic industries. The questionnaire was used as a tool for collecting information. Likert scale ranging from $(1,2,3,4,5)$ was used to measure respondent's responses. Reliability test was conducted to identify the reliability of the instrument where by values, (0.83) for organizational commitment that the scales are reliable.

\section{Search Results Analysis}

This axis includes presentation and analysis of the results demonstrated by the questionnaire and sample response analysis for the independent variable of organizational values and dependent variable of organizational commitment.

Table 1: The arithmetic mean of the organizational values

\begin{tabular}{|c|c|c|c|}
\hline variable & $\begin{array}{c}\text { Difference } \\
\text { coefficient }\end{array}$ & $\begin{array}{c}\text { standard } \\
\text { deviation }\end{array}$ & $\begin{array}{c}\text { Arithmetic } \\
\text { mean }\end{array}$ \\
\hline Reward & 28.769 & 0.725 & 2.52 \\
\hline Justice & 36.411 & 0.903 & 2.48 \\
\hline Teamwork & 30.152 & 0.793 & 2.63 \\
\hline Organization values & 29.645 & 0.753 & 2.54 \\
\hline
\end{tabular}

Table (1) shows that the question pays low level of attention to its organizational values ,the mean was (2.45) which is less than the hypothesis (3.00), the standard deviation was (0.753) and the Difference coefficient (29.645), this means that most of the respondents agree on this answer, as well as the subvalues, where all of them came below the desired level and its which are less than the hypothesis mean (3.00). This indicates the absence of the interest of the General Company for Electrical Industries Linking employees to their organizations for long-term success.

Table 2: The arithmetic mean of the organizational commitment

\begin{tabular}{|c|c|c|c|}
\hline variable & $\begin{array}{c}\text { Difference } \\
\text { coefficient }\end{array}$ & $\begin{array}{c}\text { standard } \\
\text { deviation }\end{array}$ & $\begin{array}{c}\text { Arithmetic } \\
\text { mean }\end{array}$ \\
\hline Emotional commitment & 23.206 & 0.673 & 2.90 \\
\hline Normative commitment & 22.226 & 0.649 & 2.92 \\
\hline Ongoing commitment & 29.440 & 0.895 & 3.04 \\
\hline Organization commitment & 21.050 & 0.621 & 2.95 \\
\hline
\end{tabular}

Table (2) shows that the company gives low attention organizational commitment, the mean was (2.45) which is less than the hypothesis (3.00), the standard deviation was (0.621) and the Difference coefficient (21.050),for organizational commitment which means that most respondents agree on this answer, this indicates there are low commitment of employees towards the company and there is no desire to spend the rest of their professional life in this company. The results suggest that company pays low levels of attention to both dimensions of organizational commitment, emotional commitment and normative commitment which are less than the hypothesis mean (3.00). The average mean of ongoing commitment to work with the company for different reasons such as lack of job options, leaving work many caused material and moral problems, and hoping to gain certain by continuing to work in the company.

Table 3 : Test the correlation between organizational values and organizational commitment and its sub-dimensions

\begin{tabular}{|c|c|c|c|c|}
\hline variable & $\begin{array}{c}\text { Emotional } \\
\text { commitment }\end{array}$ & $\begin{array}{c}\text { Normative } \\
\text { commitment }\end{array}$ & $\begin{array}{c}\text { Ongoing } \\
\text { commitment }\end{array}$ & $\begin{array}{c}\text { Organization } \\
\text { commitment }\end{array}$ \\
\hline Reward & $0.502 * *$ & $0.559 * *$ & $0.392 * *$ & $0.502 * *$ \\
\hline Justice & $0.499 * *$ & $0.507 * *$ & $0.316 * *$ & $0.426 * *$ \\
\hline Teamwork & $0.690 * *$ & $0.612 * *$ & $0.441 * *$ & $0.675 * *$ \\
\hline $\begin{array}{c}\text { Organization } \\
\text { values }\end{array}$ & $0.603 * *$ & $0.612 * *$ & $0.339 * *$ & $0.675 * *$ \\
\hline
\end{tabular}

Table (3) shows the correlation between the organizational values and the organizational commitment, Where the value of the correlation between them $(0.675 * *)$ at a significant level (0.01). It was also observed that there are a significant positive correlation between the sub-variables of organizational values and both of the organizational commitment and its a significant level (0.01). This suggested that if the company values are consistent with the values and objective of employees, they generate areal commitment to the company and to the nature of business. It is also observed that the value of the teamwork value is the high relationship with the organizational commitment at a value of $(0.675 * *)$. This suggested that the organizational tasks performed by teams work leads to positive relationships among employees, deepen the spirit of belonging, reduce the sense of alienation and increase the organizational commitment of employees. 


\section{International Journal of Science and Research (IJSR) \\ ISSN (Online): 2319-7064}

Index Copernicus Value (2015): 78.96 | Impact Factor (2015): 6.391

Table 3: Test the correlation between organizational values and organizational commitment and its sub-dimensions

\begin{tabular}{|c|c|c|c|c|c|c|c|}
\hline Independent variable & $\mathrm{F}$ & D.F & معنوية & ه الحد الثابت & $\mathrm{R} 2$ & $\beta$ & dependent variable \\
\hline \multirow{4}{*}{ Organization values } & 25.451 & 48 & 0.000 & 0.347 & 0.738 & 1.718 & Emotional commitment \\
\hline & 26.585 & 48 & 0.000 & 0.515 & 0.356 & 1.607 & Normative commitment \\
\hline & 6.220 & 48 & 0.000 & 0.403 & 0.115 & 2.016 & Ongoing commitment \\
\hline & 25.451 & 48 & 0.000 & 0.347 & 0.738 & 1.718 & Organization commitment \\
\hline \multirow{4}{*}{ Reward } & 16.199 & 48 & 0.000 & 0.466 & 0.252 & 1.725 & Emotional commitment \\
\hline & 21.815 & 48 & 0.000 & 0.501 & 0.212 & 1.654 & Normative commitment \\
\hline & 8.712 & 48 & 0.000 & 0.484 & 0.154 & 1.820 & Ongoing commitment \\
\hline & 22.466 & 48 & 0.000 & 0.484 & 0.319 & 1.733 & Organization commitment \\
\hline \multirow{4}{*}{ Justice } & 15.888 & 48 & 0.000 & 0.371 & 0.249 & 1.979 & Emotional commitment \\
\hline & 16.605 & 48 & 0.000 & 0.364 & 0.257 & 2.012 & Normative commitment \\
\hline & 1.029 & 48 & 0.000 & 0.144 & 0.021 & 2.684 & Ongoing commitment \\
\hline & 10.669 & 48 & 0.000 & 0.293 & 0.182 & 2.225 & Organization commitment \\
\hline \multirow{4}{*}{ Teamwork } & 43.583 & 48 & 0.000 & 0.586 & 0.476 & 1.363 & Emotional commitment \\
\hline & 28.723 & 48 & 0.000 & 0.501 & 0.374 & 1.601 & Normative commitment \\
\hline & 1.029 & 48 & 0.000 & 0.144 & 0.021 & 2.684 & Ongoing commitment \\
\hline & 11.618 & 48 & 0.000 & 0.528 & 0.499 & 1.731 & Organization commitment \\
\hline
\end{tabular}

Table (4) shows that there is a significant effect of the organizational values in the organizational commitment and its subdivisions. The calculated value of $(F)$ is (25.451), which is naturally greater than the $(F)$ table value of (2.462) and the freedom level (48) in signification level (0.01), with a confidence level (99\%), and the coefficient of stability $(\alpha)$ reached (0.347), This means that if the organizational values are equal to zero, the organizational commitment variable will not be less than this value. The value of the (R2) for the total variable of organizational values (0.738). The independent variable (organizational values) is capable of interpreting ( $73.8 \%$ ) Of changes to the approved variable (organizational commitment), the remaining (26.2\%) represented significant elements and variables that did not appear in the model. The value of the Coefficient of marginal inclination $(\beta)$ was (1.718), the increase in the organizational values by one unit will necessarily increase the organizational commitment $(171.8 \%)$. It was also observed that the sub-dimension of organizational value have a significant effect on both organizational commitment and the sub-dimension of organizational commitment, except the sub- dimensions of justice and teamwork that have no effect on sub- dimension of ongoing commitment.

\section{Conclusion}

In answering the research question, the analysis revealed that there are correlation and positive effect relationships between organizational values are the logic of organization which reflects the future orientation, the image and reputation, and commitment of employee. Organizational values represent the starting point for the future direction of the organization, its reputation and feature of organization. Values are an important source to attract the skilled human resources that seek to achieve their goals through the goals and values adopted by the organization. Therefore, organizations should increase their investments in the organizational values. Organization should make organizational values the basic rule for guiding organization's work in a manner consistent with the personal values of employees. Organization should work to satisfy needs and wants of employees in order to increase their organizational commitment.

\section{References}

[1] Abdul Rahim, Atef Jabr Taha, (2014), "The Impact of Organizational Values on Managers on Organizational Consensus and Labor Values, Quantitative Study on a Number of Directors", Journal of Al-Quds University for Research and Studies, No. (33), pp. (300-354).

[2] Al-Farajat, K. \& Al-Lozi, M. S and Al-Shihabi, I, (2009), Organizational Behavior - Contemporary Concepts, First Edition, Enrichment for Publishing and Distribution, Amman.

[3] Francis, D. \& Woodcock, M.,(1992), Organizational Values, translated by Abdel Rahman Ahmed Heegan, Review Wahid Ahmed Al Hindi and Amer Abdullah Al - Saghiri, Riyadh

[4] Al-Lozi,, M. S (2007), Organization and Work Procedures, Second Edition, Dar Wael Publishing and Distribution, Amman.

[5] Padaki, V, (2000), "Coming to grips with organizational values" Taylor \& Frances group, Vol.10, No.3, p.p (435-420).

[6] Amis , J \& Slack , T. \& Hinings , C.R ,(2002) "Values and Organizational Change" . Journal of Applied Behavioral Science. Vol. 38, Issue. 4, p.p (400-443).

[7] Malbasic , I \& Brcic , R, (2012) ,"Organizational Values in managerial communication" ,Management,Vol.17,No.2,p.p (99-118).

[8] Goodstein, L.,D,(1983), " Managers values, and organization Development", Sage publication Inc, Vol. 8, No. 2, p.p (203-220).

[9] Kabanoff, B \& Daly, J,(2002), " Espoused values of organizations", Australian journal of management, Vol. 27, p.p(104-89).

[10] Speculand, R \& Chaudhary, R, (2008), " Living organizational values: The bridges value inculcation model" , Business strategy series, Vol.9, Issue. 6, p.p (324-329)

[11] Hellregel, D \& Slocum, J.W, (2011),13th e.d, ,Organization Behavior, Cengage learning, Southwestern.

[12] Dogan, S\& Aydin ,B , (2012), "The relationship between organizational value and organizational commitment in public and private universities", 


\section{International Journal of Science and Research (IJSR) \\ ISSN (Online): 2319-7064}

Index Copernicus Value (2015): 78.96 | Impact Factor (2015): 6.391

African Journal of Business Management, Vol.6, Issue.6, p.p (2115-2107).

[13] Bissett, M.,F,(2014), The role of values and value congruence for job satisfaction, person organization fit work engagement and resilience, A dissertation submitted in partial fulfilment of the of the requirements for the degree of master of science in applied psychology at the university of Canterbury.

[14] Prezision, R.C\& Gooden, D.J , (2011) , " The relationship between values congruence and innovation capability" International business \& economics journal, Vol. 1, No. 8, p.p (34-30).

[15] Vveinhardt, J\& Gulbovait,E \& Streimikiene, D, (2016), "Values congruence from the executives viewpoint: Value- based practice" Interdisciplinary approach to economics and sociology, Vol. 9, No.2, p.p (265-248).

[16] Hoffman, B .J\& Bynum, B.,H\& Piccolo, R.F\& Sutton, A.W, (2011), " Person- organization value congruence: How transformational leaders Influence work group effectiveness", Academy of management journal, Vol.54,No.4,p.p(779-796).

[17] Diskiene , D \& Gostautas , V, (2013) "A Fit Between individual and Organizational Values and its implications for employees job satisfaction and performance". faculty of economics , Department of Management ,Vilnius University Lithuania . Vol.92 .No.2 p.p (93-107) .

[18] AlShamma, K. M. H \& Hamoud, K . K , (1989), The Theory of Organization , House of Public Cultural Affairs, Baghdad.

[19] Hassan, M. H, (1989), Flag of the Organization, Directorate of Dar al-Ketub for printing, Mosul, Iraq.

[20] Taheri, F \& Soltani, E,(2013), "The Study Of Organizational Justce Effect On Job Satisfaction \& Organizational Citizenship Behavior ,( Case Study ,Organization Of Roads \& Urban Development Of Golsestan State", World Of Sciences Journal Vol .1 Issue (15) p.p (64-73).

[21] AlZoghbi, K (2008), "The Impact of Commitment on Cultural and Organizational Values on the Level of Performance of Workers in the Public Sector in Karak Governorate", King Abdulaziz University Journal, Vol 22, No.1, pp.(11-27).

[22] Mollahosseini, A\& Karnama, A\& Mirhosseyni, M.S. L, (2012), " Investigating the relationship between perception of justice and customer oriented boundary spanning behaviors" International journal of business and social science. Vol.3, No,3, p.p (301-306).

[23] Aldulaimi, H.T \& Handal, Q. A \& Abed G. F, (2014), "The Effect of Organizational Values on the Performance Efficiency Field Study in the General Directorate of Salahuddin Education" Vol. 4, No. 2, p.p (32-1).

[24] Robbins, S.P \& Judge, T.A,(2007), 12th.ed , Essentials of organizational behavior, Pearson prantice Hall, New Jersey.

[25] Saber, B, (2014), "Organizational Values and their Relationship to the Empowerment of the Human Resource, A Field Study at the Faculty of Social and Social Sciences" Note for Master's Degree in Psychology Work Organization, Mohammed Khudair
University - Biskra.

[26] Hyde , R.E \& Weathington ,B.L, (2006) "The Congruence of Personal life Values and Work Attitudes" , Genetic Social and General Psychology Monographs ,Vol. 132, Issue. 2, p.p (151-169).

[27] Jing, C \& Hua, S. X, (2009)," The Relationship Research among Organizational Commitment, Employee Satisfaction and Work Performance", International Conference on Management Science \& Engineering, Vol.16.

[28] Eslami , J \& Ghorakhani ,D, (2012) , "Organizational .commitment and Job satisfaction" , Journal of science and technology Vol 2 ,No 2 p.p (85-91).

[29] Abdullah, A (2011), "Evolution of Allen and Meyer's Organizational Commitment Scale: A Cross - Cultural Application in Pakistan", Journal of Education and Vocational Research, Vol.1, No.3, p.p (80-86).

[30] Danish, R.Q \& Ramzan, S \& Ahmad, F., (2015), "Effect of Formalization on Organizational Commitment; Interactional Role of Self-Monitoring in the Service Sector", American Journal of Economics, Finance and Management Vol. 1, No. 4, p.p ( 229. 235).

[31] Obalola, M \& Aduloju, K \& Olowokudejo, F,(2012)," Organizational Commitment and Corporate Ethical Values:Exploring the Nexus between Employees' Psychological Contract and Firms' Ethical Behaviour in the Nigerian Insurance Industry", Journal of Management and Sustainability Vol. 2, No. 1, p.p (4356).

[32] Dion, K.W ,(2011) “ A. Retrospective study of Anurse Residency program and Reports of Job satisfaction organization commitment and Turnover", The University of . Texasat Austin.

[33] Huang, C-C. \& You, C-S, (2011), "The Three Components of Organizational Commitment on inRole Behaviors and Organizational Citizenship Behaviors", African Journal of Business Management, Vol.5, No.23, p.p.( 11335- 11344).

[34] Bhatti, K.K \& Nawab, S. \& Akbar, A., (2011), "Effect of Direct Participation on Organizational Commitment", International Journal of Business and Social Science, Vol. 2, No. 9, p.p (15-23).

[35] Chaghtai, A.A \& Zafar, S., (2006), "Antecedents and consequences of Organizational Commitment" Among Pakistani University teachers, Applied H.R.M. Research, Vol. 11, No. 1.

[36] Dunham ,R.B. \& Grube ,J.A., \& Castande ,M.B,.(1994), "Organizational Commitment : the utility of an Integrative Definition" , Journal of Applied Psychology, Vol.79,No.3.

[37] Jamal, M., (2011), "Job Stress, Job Performance and Organizational Commitment in a Multinational Company: An Empirical Study in Two Countries", International Journal of Business and Social Science Vol.2, No.20, p.p( 20- 29).

[38] Brown, B.B., (2003), "Employees' Organizational Commitment and Their Perception of Supervisor's Relation's- Oriented and Task- Oriented Leadership Behaviors", Virginia State University.

[39] Mcshane, s\& Glinow, M (2007), organizational behavior essinationals , McGraw-hill/Irwin, N.Y,

\section{Volume 6 Issue 12, December 2017}


USA,.

[40] Mathebula, M, R .L (2004), "Modelling the relationship Between Organizational commitment leader ship style Human Resources management Practices and Organization Trust" ,, Master thesis University of Pretoria .

[41] Meyer , JP \& Allen NJ .(1991), "Three component conceptualization of Organizational commitment ". Human Resource Management . Vol 1 ,No1

[42] Ashman ,I \& Winstanley, D (2006), "The ethics of Organizastional commitment ; Business . Ethics " A European Review Vol .15 ,No 2, p.p (142-153).

[43] Dagher, M \& Saleh, A. H (2000), Organization Theory and Organizational Behavior, Baghdad University Press.

[44] Jaros, S,(2007)," Meyer and Allen Model of Organizational Commitment: Measurement Issues",The Icfai 24 Journal of Organizational Behavior, Vol. 5, No. 4.

[45] Kaur, K, \& Sandhu, H.S. \& Kaur, K, (2010), "Career Stage Effect on Organizational Commitment: Empirical Evidence from Indian Banking Industry" International Journal of Business and Management Vol. 5, No. 12, p.p (141-152).

[46] Wen Liu, S \& Norcio, R \& Tsung T. J, (2009), "The Differences in Job Characteristics, Job Satisfaction, and Organizational Commitment of Taiwanese Expatriates Working in Mainland China" International Journal of Business and Management; Vol. 4, No. 11, p.p (11-17).

[47] Nazeri, A \& Meftahi, K. R, (2012)," Relationship between welfare staff and organizational commitment in the control center of the Central Registration Office", Management Science Letters, Vol.2, p.p (1779-1784)

[48] Tumwesigye, G, (2010)," The relationship between perceived organizational support and turnover intentions in a developing Country: The mediating role of organizational commitment", African Journal of Business Management Vol. 4, No.6, p.p (942-952).

[49] Panaccio, A,\& Vandenberghe, C (2009)," Perceived organizational support, organizational commitment and psychological well-being: A longitudinal study", Journal of Vocational Behavior, Vol.75, p.p (2242360).

\section{Author Profile}

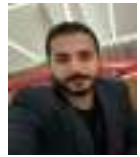

Mustafa AbdulAbaas obtained the degree of Bachelor of Science in Public Administration (2014) from the Faculty of Administration and Economics 1 University of Baghdad. Then he joined higher studies at the same Faculty, this research report now is one of the requirements for the attainment of a master's degree in Management Sciences $\backslash$ specialization in organizational behavior.

Nisreen Jasim Mohammed Professor in the Faculty of Management and Economics/ University of Baghdad/ Department of Public Administration. She a specialist in the strategic management for more than (10) years, and she the professor of strategic management in higher studies, and President of the Department of Public Administration in the same faculty.

Volume 6 Issue 12, December 2017 www.ijsr.net 